\title{
Thermal decomposition of selected chlorinated hydrocarbons during gas combustion in fluidized bed
}

Malgorzata Olek ${ }^{1 *}$, Jerzy Baron ${ }^{2}$ and Witold Zukowski ${ }^{1}$

\begin{abstract}
Background: The process of thermal decomposition of dichloromethane (DCM) and chlorobenzene (MCB) during the combustion in an inert, bubbling fluidized bed, supported by LPG as auxiliary fuel, have been studied. The concentration profiles of $\mathrm{C}_{6} \mathrm{H}_{5} \mathrm{Cl}, \mathrm{CH}_{2} \mathrm{Cl}_{2}, \mathrm{CO}_{2}, \mathrm{CO}, \mathrm{NO}_{x}, \mathrm{COCl}_{2}, \mathrm{CHCl}_{3}, \mathrm{CH}_{3} \mathrm{Cl}_{2} \mathrm{C}_{2} \mathrm{H}_{2}, \mathrm{C}_{6} \mathrm{H}_{6}, \mathrm{CH}_{4}$ in the flue gases were specified versus mean bed temperature.

Results: The role of preheating of gaseous mixture in fluidized bed prior to its ignition inside bubbles was identified as important factor for increase the degree of conversion of DCM and MCB in low bed temperature, in comparison to similar process in the tubular reactor.

Conclusions: Taking into account possible combustion mechanisms, it was identified that autoignition in bubbles rather than flame propagation between bubbles is needed to achieve complete destruction of DCM and MCB. These condition occurs above $900^{\circ} \mathrm{C}$ causing the degree of conversion of chlorine compounds of $92-100 \%$.
\end{abstract}

\section{Background}

Chlorine derivatives of aliphatic and aromatic hydrocarbons are a group of compounds produced on a large scale. These substances are persistent environmental pollutants. Their degradation in nature is slow due to the presence of covalent bonds in their molecules and also they are often xenobiotics. Combustion is one of possible methods for chlorinated hydrocarbons ( $\mathrm{CHCs}$ ) destruction. Taking into account the average bond enthalpy [1] of C-Cl $(338 \mathrm{~kJ} / \mathrm{mol})$ to $\mathrm{C}-\mathrm{C}(348 \mathrm{~kJ} / \mathrm{mol})$ and $\mathrm{C}-\mathrm{H}(412 \mathrm{~kJ} / \mathrm{mol}))$, at the elevated temperature chlorine should be easily dissociated. The main products of the process will be stable $\mathrm{H}_{2} \mathrm{O}, \mathrm{CO}_{2}$ and $\mathrm{HCl}$ easily separated in scrubbers.

Fluidized bed incineration is one of technology which can be used in gaseous and liquid waste disposal. Usually wastes have low calorific value and auxiliary fuel (e.g. gaseous fuel) is needed to achieve stable combustion process. It is well known that in bubbling fluidized bed,

\footnotetext{
*Correspondence: molek@pk.edu.pl

'Department of Thermal Engineering and Air Protection, Faculty of Environmental Engineering, Cracow University of Technology, Warszawska 24, Cracow 31-155, Poland

Full list of author information is available at the end of the article
}

gaseous fuel can be efficiently burnt [2-8]. The process of fuel conversion in inert bed material (eg. sand) is result of radical processes occurring in the bubbles $[9,10]$. Combustion inside the bubbles has periodic character and are accompanied by pressure pulsations and visual effects [11-14]. Gaseous mixture fed into the fluidized bed quickly reach its temperature, and then the temperature inside the bubbles reach values of several hundred degrees higher than the temperature of the fluidized bed [14]. The effect of overheating the gas mixture inside the bubbles can be used in the processes of waste disposal when the heteroatoms are present in them. Especially when heteroatoms such as $\mathrm{Cl}$ or $\mathrm{Br}$ participating in radical reactions they may cause the inhibition of the combustion process.

The combustion of solid and gaseous fuels in a fluidized bed in the presence of halogen derivatives have been studied before, but only concentration of $\mathrm{CO}$, NO, $\mathrm{NO}_{2}$ have been analyzed. The general consensus was that the halogens have an inhibitory effect on the combustion process $[15,16]$. The inhibition is due to catalytic effect of $\mathrm{Cl}$ radicals on the process of recombination of $\mathrm{O}, \mathrm{H}, \mathrm{OH}$, and $\mathrm{HO}_{2}$ radicals. It was found that the presence of $\mathrm{HCl}$ inhibits the oxidation of $\mathrm{CO}$ to $\mathrm{CO}_{2}$ and
(C) Chemistry Central

C 2013 Olek et al.; licensee Chemistry Central Ltd. This is an Open Access article distributed under the terms of the Creative Commons Attribution License (http://creativecommons.org/licenses/by/2.0), which permits unrestricted use, distribution, and reproduction in any medium, provided the original work is properly cited. 
decreases the formation of $\mathrm{NO}$ in the flue gas. This effect of halogen on $\mathrm{CO}$ and $\mathrm{NO}$ concentrations in flue gases was confirmed in other works [17-21].

As studies [13] and [14] show the combustion process of gaseous fuels in a bubbling fluidized bed in the temperature range of $300-1000^{\circ} \mathrm{C}$ is carried out at a certain height above the distributor. It has also been shown that one can designate two characteristic bed temperatures $\left(\mathrm{T}_{\mathrm{cr} .1}\right.$ and $\left.\mathrm{T}_{\mathrm{cr} .2}\right)$, which enable distinguishing of three temperature ranges (combustion regime $\mathrm{A}, \mathrm{B}$ and C). These regimes are associated with different physical mechanisms of combustion. According to [14] in regime A a mixture of gaseous fuel and air burn in flame above fluidized bed. During regime $B$ and $C$ it burn inside the bed in bubbles. Between $T_{\text {cr.1 }}$ and $T_{\text {cr.2 }}$, in regime $B$, combustion process in the bubbles is possible as a result of flame propagation between bubbles. During regime $\mathrm{C}$ - when the temperature of the bed is higher than the critical temperature $\mathrm{T}_{\mathrm{cr} .2}$ - the burning occurs as a result of self-ignition of the fuel mixture in bubbles $[13,14,22]$. The composition of the flue gases strongly dependences on type of combustion regime. It have been described earlier (for methane and ethane) $[13,14]$ and will be briefly discussed later in this work (for LPG).

The aim of present work was to determine how the addition of selected chlorinated hydrocarbons influences the fluidized bed combustion over the range $300-1000^{\circ} \mathrm{C}$. This was done to recognize possibility of using the reactor with an inert fluidized bed to decompose selected chlorinated hydrocarbons. Measurements of concentration of chlorine byproduct in the flue gases, under different combustion regimes were also performed. The concentration profiles of initial, final and byproduct compounds were determined as a function of mean bed temperature. The profile of degree of DCM and MCB decomposition were compared with results obtained in tubular reactors, based on data from literature.

\section{The experiment}

\section{Materials, apparatus and analytical methods}

Liquefied petroleum gas (LPG) was used as hydrocarbon fuel supporting combustion process in all experiments. Dichloromethane (DCM) and chlorobenzene (MCB) both technical grade - were chosen as chlorinated hydrocarbons. All experiments were done in lab stand, illustrated in Figure 1. The main element of it was a reactor built from a $500 \mathrm{~mm}$ transparent quartz tube (Figure 1, part 4, $96 \mathrm{~mm}$ internal diameter) resting on a $1 \mathrm{~mm}$ thick perforated plate Figure 1, part 8) and plenum chamber (Figure 1, part 9). The bed material was quartz sand (300 g, particle size 0.3 to $0.385 \mathrm{~mm}$ ) with static height of $29 \mathrm{~mm}$. Sand was fluidizing by a LPG and air heated to $80^{\circ} \mathrm{C}$ and mixed in plenum chamber. The air excess was $1.20( \pm 0.02)$. Both $\mathrm{DCM}$ and $\mathrm{MCB}$ were injected to the evaporator and then to the fluidizing air. The combustion process was initiated by a pilot flame (Figure 1, part 10) located in the freeboard. The bed temperature was regulated by a movable cylindrical

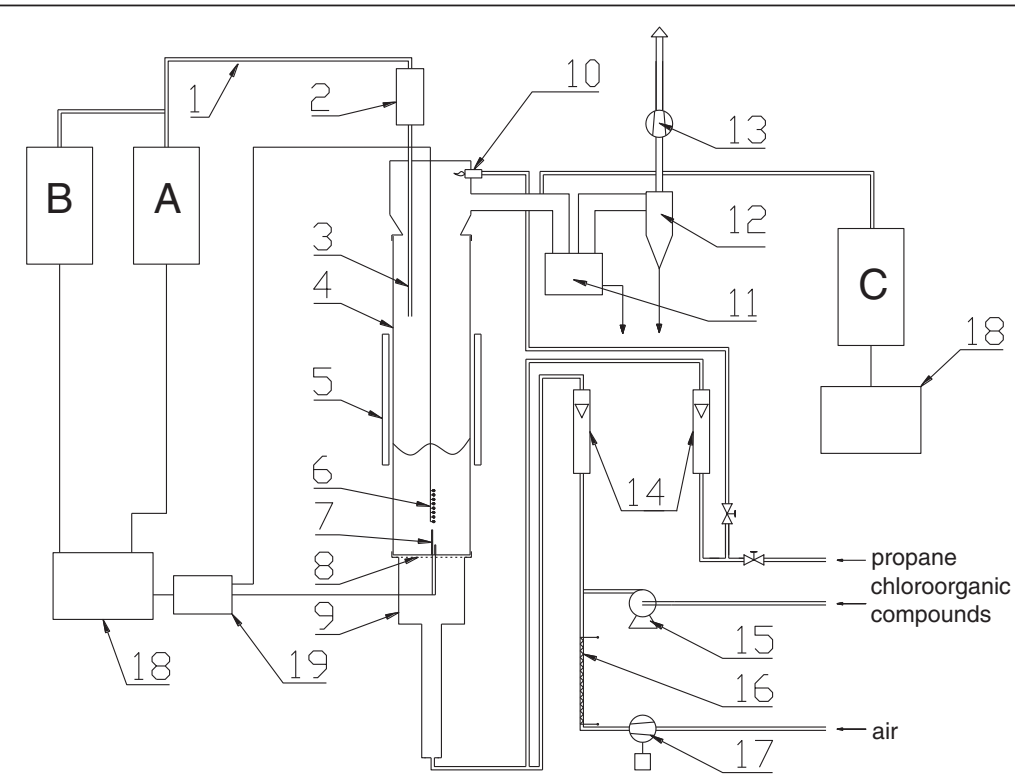

Figure 1 Schematic of the lab stand. 1- heated probe for sampling the flue gases, 2 - dust filter, 3- probe, 4- quartz pipe, 5- insulating shield, 6 - set of 8 . thermocouples, 7 - two thermocouples, 8 - perforated plate, 9 - plenum chamber, 10 - pilot flame, 11 - ash trap for coarse particles, 12 - cyclone, 13- flue gases fan, 14 - rotameters, 15 - Infusion pump, 16 - electric heater, 17 - blower, for fluidizing air, 18 - computers storing chemical analyses quantities and temperature, 19 - A/D convertor for thermocouple signal, A - Horiba PG-250 analyzer, B - J.U.M. 3-200 analyzer, C - Gasmet ${ }^{\mathrm{TM}}$ DX-4000 IR spectrum analyzer. 
insulating shield (Figure 1, part 5), which surrounded the quartz pipe and by additional fan ensured the cooling of the reaction zone. The temperature of the combustion chamber was measured using ten thermocouples (Ni-CrNi). Two of them (Figure 1, part 7) mounted from bottom, were located 20 and $50 \mathrm{~mm}$ above the distributor. Set of eight (Figure 1, part 6) mounted from above, were located in the axis of the reactor one above the other at a height of $5,12,20,29,40,50,60$ and $70 \mathrm{~mm}$ above the distributor.

Flue gases were monitored by a set of analyzers. The most important element of the analytic set was a Gasmet $^{\mathrm{TM}}$ DX-4000 IR spectrum analyzer (Figure 1, part C). It utilizes Michelson interferometer to obtain spectrum of analyzed gaseous sample. After Fourier transformation of interferogram concentration of selected compounds were calculated. The gas sample was periodically analyzed to determine concentration of $\mathrm{HCl}, \mathrm{CHCl}_{3}$, $\mathrm{CH}_{3} \mathrm{Cl}, \mathrm{CH}_{2} \mathrm{Cl}_{2}, \mathrm{COCl}_{2}, \mathrm{C}_{6} \mathrm{H}_{5} \mathrm{Cl}, \mathrm{CH}_{4}, \mathrm{C}_{2} \mathrm{H}_{2}$ and $\mathrm{C}_{6} \mathrm{H}_{6}$. Concentrations of $\mathrm{CO}_{2}, \mathrm{CO}, \mathrm{NO}$ and $\mathrm{O}_{2}$ were continuously monitored using a Horiba PG-250 analyzer (Figure 1, part A). A J.U.M. 3-200 analyzer (Figure 1, part B) was used to monitor VOCs (volatile organic compounds). Concentrations of $\mathrm{CO}_{2}$ and $\mathrm{CO}$ were measured using non-dispersive infrared detector (NDIR), $\mathrm{NO}_{\mathrm{x}}$ and $\mathrm{O}_{2}$ concentrations were determined using chemiluminescence (CLA) and electrochemical (EC) method respectively. The total concentration of VOCs was determined by using a flame-ionization method (FID). The accuracy of the measurement equipments for different species was as follow: $\mathrm{CO}$ and $\mathrm{NO}-1 \mathrm{ppm}$, $\mathrm{CO}_{2}, \mathrm{O}_{2}-0.1 \%$ vol., VOC $-0.1 \mathrm{ppm}, \mathrm{HCl}, \mathrm{CHCl}_{3}$, $\mathrm{CH}_{3} \mathrm{Cl}, \mathrm{CH}_{2} \mathrm{Cl}_{2}, \mathrm{COCl}_{2}, \mathrm{C}_{6} \mathrm{H}_{5} \mathrm{Cl}, \mathrm{CH}_{4}, \mathrm{C}_{2} \mathrm{H}_{2}$ and $\mathrm{C}_{6} \mathrm{H}_{6}-$ $2 \mathrm{ppm}$.

\section{Research methodology}

At the beginning of experiment run the bed of sand was fluidized by air $\left(1.66 \mathrm{dm}^{3} / \mathrm{s}\right.$ in normal conditions), which temperature was $80^{\circ} \mathrm{C}$. Then a constant stream of chloroorganic additive was injected into the air. After dosing of hydrocarbon fuel the combustion process was initiated. The bed was gradually heated from c.a. $80^{\circ} \mathrm{C}$ to $1000^{\circ} \mathrm{C}$ at rate $\sim 1.5 \mathrm{~K} / \mathrm{s}$ and for $180 \mathrm{~s}$ the process was carried out isothermally. Afterwards the bed was cooled down to c.a. $800^{\circ} \mathrm{C}$. Then it was heated again to $1000^{\circ} \mathrm{C}$. After next $180 \mathrm{~s}$ the process was ended by turning off the supply of chlorine additives and next by cutting off the supply of hydrocarbon fuel. Initial concentrations of DCM introduced into the reactor were as follows: 1100 $\mathrm{ppm}\left(\mathrm{DCM}^{1}\right), 2700 \mathrm{ppm}\left(\mathrm{DCM}^{2}\right)$ and $5350 \mathrm{ppm}$ $\left(\mathrm{DCM}^{3}\right)$. Similar experiments were carried out using $\mathrm{MCB}$ to give initial concentration of $900 \mathrm{ppm}\left(\mathrm{MCB}^{1}\right)$, $1800 \mathrm{ppm}\left(\mathrm{MCB}^{2}\right)$ and $3650 \mathrm{pmm}\left(\mathrm{MCB}^{3}\right)$, respectively. To be able to find the influence of chloroorganic addition on combustion process, a reference experiment (w/o chloroorganic compounds addition) were also carried out. In the following discussion the results for the middle concentration of DCM and MCB have been consistently ignored because the results were located between values obtained for lower and higher concentrations of additives.

\section{The results and discussion}

\section{The effect of additives on the combustion process}

The addition of DCM or MCB to LPG-air mixture causes changes in the process of combustion in a fluidized bed. These changes are analyzed using vertical temperature profiles registered inside the fluidized bed under different conditions. Figure 2 illustrated, as a stepped curve, the position of the highest bed temperature as a function of mean bed temperature. Red line shows location of dynamic bed surface. Taking into account previous considerations $[13,14,22]$, the analysis of the stepped curve indicates two characteristic critical temperatures $\left(T_{\text {cr.1 }}\right.$ and $\left.T_{\text {cr.2 }}\right)$ for each combusted mixture.

Figure 2A shows the reference data achieved during LPG combustion. Until the bed reaches the mean temperature of $535^{\circ} \mathrm{C}$ location of the combustion is above the line representing the location of the bed's surface i.e. the combustion of LPG occurred in flame above the bed (Figure $3 \mathrm{~A})$. Over $\mathrm{T}_{\text {cr.1 }}$ the LPG combustion regime changed from continuous combustion above the bed to periodic combustion inside the bubbles. It occurred mostly inside the bubbles in the upper part of the bed (Figure 3B). Further temperature increase cause a slight change in location of the LPG combustion zone. Over $535^{\circ} \mathrm{C}\left(\mathrm{T}_{\text {cr. } 1}\right)$, but below $830^{\circ} \mathrm{C}\left(\mathrm{T}_{\text {cr. } 2}\right)$ the combustion was located inside the bed, $40-50 \mathrm{~mm}$ above the distributor, due to flame propagation between adjusted bubbles [13]. The dynamic height of the bed in this temperature range was between $50-75 \mathrm{~mm}$. After exceeding $830^{\circ} \mathrm{C}\left(\mathrm{T}_{\mathrm{cr} .2}\right)$ autoignition of the mixture in the bubbles occurred before it reached the bed's surface (regime C) (Figure 3C). Above $900^{\circ} \mathrm{C}$ the location of the most intense reactions was c.a. $5 \mathrm{~mm}$ above the distributor. (Figure 3D).

Adding of DCM (concentration $900 \mathrm{ppm}-\mathrm{DCM}^{1}$; Figure 2B) or MCB (concentration $1100 \mathrm{ppm}$, Figure 2C) to the reacting mixture did not change the values of critical temperatures, $\mathrm{T}_{\mathrm{cr} .1}^{\prime}$ and $\mathrm{T}_{\mathrm{cr} .2}$ were $535^{\circ} \mathrm{C}$ and $830^{\circ} \mathrm{C}$ respectively. Increasing the DCM concentration in the mixture at $5350 \mathrm{ppm}$ and $\mathrm{MCB}$ to $3650 \mathrm{ppm}$ increased the first critical temperature to $\mathrm{T}^{\prime \prime}{ }_{\mathrm{cr} .1}=560^{\circ} \mathrm{C}$ (Figure 2B) and $\mathrm{T}^{\prime \prime}{ }_{\text {rr. } 1}=585^{\circ} \mathrm{C}$ (Figure $2 \mathrm{C}$ ). The second critical temperature was also changed. $\mathrm{T}_{\mathrm{rr} .2}=840^{\circ} \mathrm{C}$ for $\mathrm{DCM}$. After introducing $\mathrm{MCB}$ into the reactor $\mathrm{T}_{\text {cr.2 }}$ decreased to $800^{\circ} \mathrm{C}$ (Figure $2 \mathrm{C}$ ). 

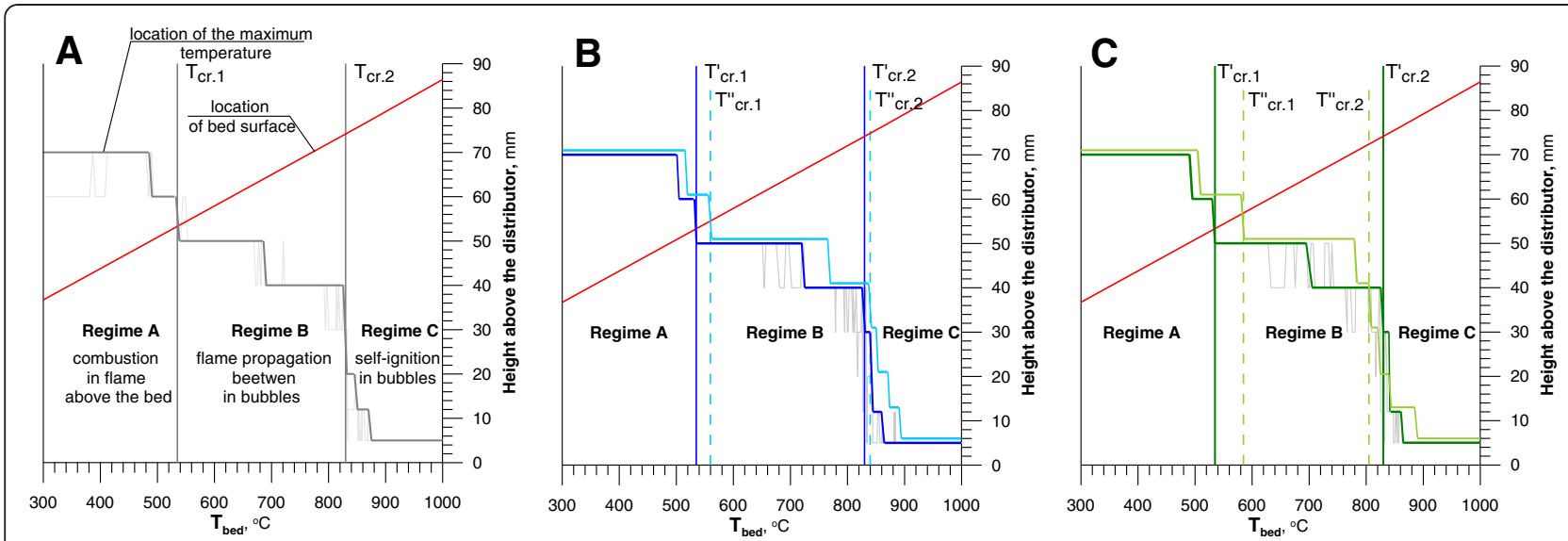

Figure 2 Location of the maximum bed temperature and bed surface in relation to the average temperature of the bed. A - experiment without the addition of chlorinated hydrocarbons, $\mathbf{B}$ - addition different streams of DCM, C - addition different streams of MCB (red lines- dynamic bed height; stepped lines - the position of maximum temperature: gray line - only LPG, navy blue line - 1100 ppm DCM, blue line - 5350 ppm DCM, dark green line - 900 ppm MCB, light green line - 3650 ppm MCB; continuous and dashed vertical lines indicated the critical temperature $\left(T_{c r .1}, T_{c r .2}\right.$ - experiment without the addition of chlorinated hydrocarbons, $T_{c r .1}^{\prime}, T_{c r .2}^{\prime}-1100$ ppm DCM or 900 ppm MCB, $T_{c r .1}^{\prime \prime}, T_{c r .2}^{\prime \prime}-5350$ ppm DCM or 3650 ppm MCB).
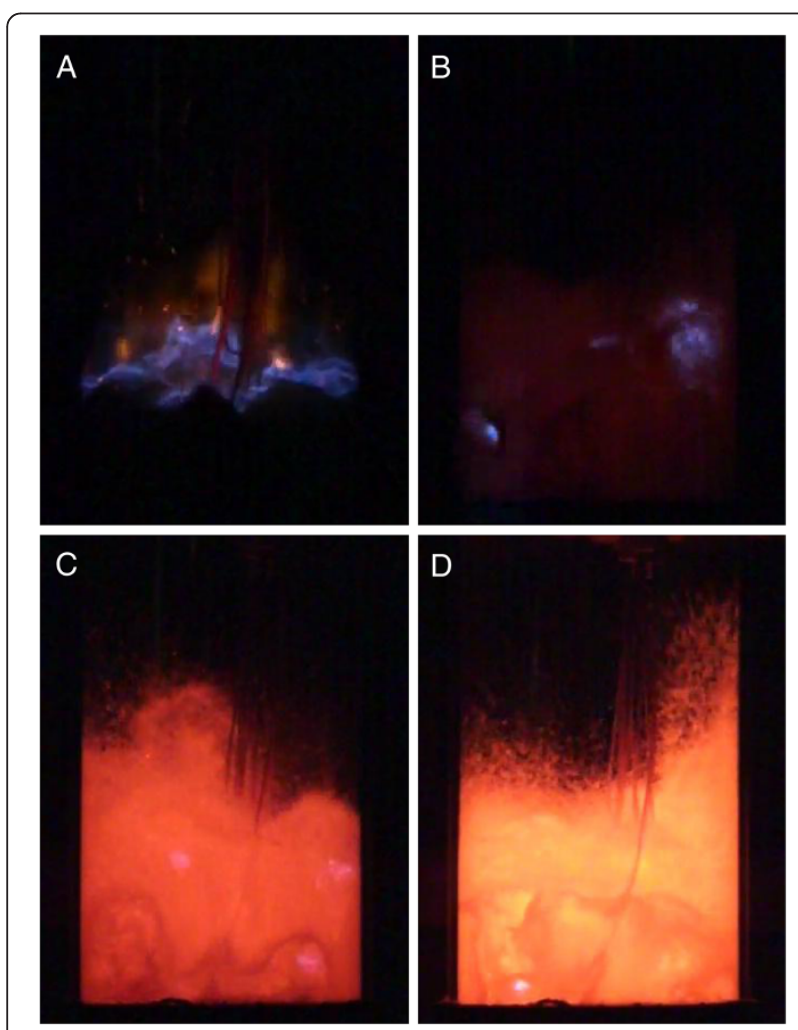

Figure 3 Stages of combustion of gaseous fuel in a fluidised bed reactor ( $A$ - Combustion over the fluidized bed's surface, Regime $A, T_{\text {bed }}=200^{\circ} \mathrm{C}$, the edges of the reactor is not visible, $B$ - Combustion in a bubble leaving the fluidized bed, Regime $B, T_{\text {bed }}=710^{\circ} \mathrm{C}, \mathrm{C}$ - Combustion inside the fluidized bed. Regime $C, T_{\text {bed }}=870^{\circ} \mathrm{C}, \mathrm{D}$ - Combustion inside the fluidized bed, Regime $\mathrm{C}$, $\mathrm{T}_{\text {bed }}=920^{\circ} \mathrm{C}$.
The increase of the first and second critical temperature, in presence of DCM, is caused by its influence on the LPG combustion mechanism. The oxidation process in bubbling fluidized bed of inert material depends on the formation of $\mathrm{H}$ and $\mathrm{OH}$ free radicals. When $\mathrm{Cl}$ radicals are present at higher concentration following reactions should be taken into consideration [21]:

$$
\begin{aligned}
& \mathrm{Cl}+\mathrm{H}+\mathrm{M}->\mathrm{HCl}+\mathrm{M} \\
& \mathrm{HCl}+\mathrm{H}(\mathrm{OH})->\mathrm{H}_{2}\left(\mathrm{H}_{2} \mathrm{O}\right)+\mathrm{Cl}
\end{aligned}
$$

In total they cause recombination of free radical concentration in reactor:

$$
\mathrm{H}+\mathrm{H}(\mathrm{OH})->\mathrm{H}_{2}\left(\mathrm{H}_{2} \mathrm{O}\right)
$$

As a result, the combustion of LPG in the presence of DCM is inhibited.

Different effects on the combustion process were observed when $3650 \mathrm{ppm}$ of MCB was injected. Lowering $\mathrm{T}_{\text {cr.2 }}$ means that not every chlorinated hydrocarbon has negative impact on the combustion process. This follows from the fact that the molar ratio $\mathrm{C}: \mathrm{H}: \mathrm{Cl}$ in the MCB (6:5:1) is different than in DCM (1:2:2).

\section{Products of LPG combustion in the presence of chlorinated hydrocarbons}

The concentrations of $\mathrm{CO}_{2}, \mathrm{CO}$ and VOCs at different mean bed temperature are presented in Figure 4.

Under regime A, below $200^{\circ} \mathrm{C}$, the fluidization did not cause a significant turbulence on bed's surface. LPG burns in the flame over the bed's surface. Some of the solid particles were transported to the rare zone (freeboard) of the reactor. In that case combustion was 


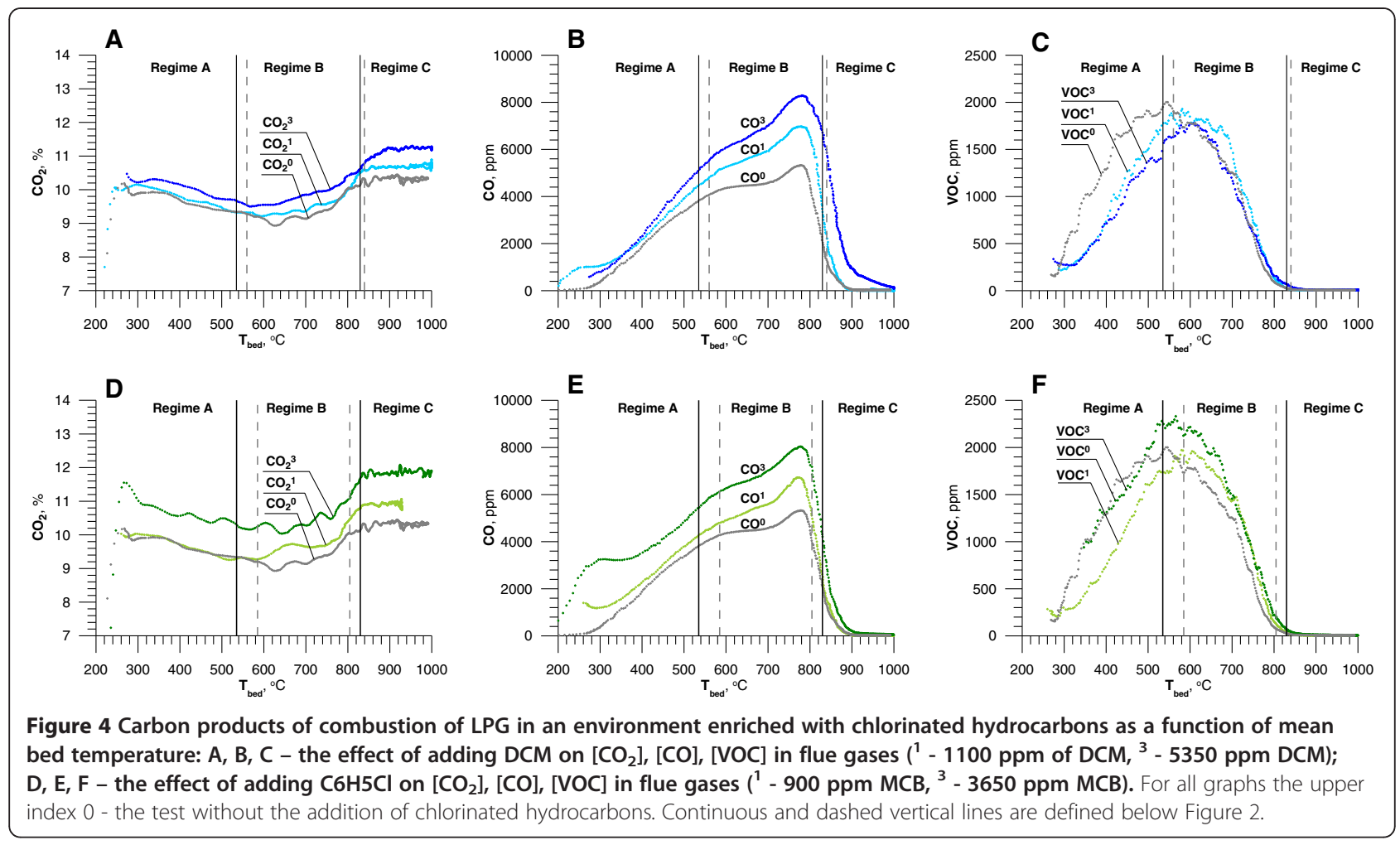

almost completed and $\mathrm{CO}_{2}$ was the main carbon product. While the temperature increased, the velocity of gases and the turbulence of the fluidization increased and more solid particle were transported into the rare zone. The recombination of the radicals occurred on the surface of them. As the result a decrease of $\left[\mathrm{CO}_{2}\right]$ and an increase of $[\mathrm{CO}]$ and $[\mathrm{VOC}]$ in the flue gases were observed (Figure $4 \mathrm{~B}$ and $\mathrm{C}$ ). Under regime $\mathrm{B}$ the combustion occurred in the large bubbles close to the bed's surface. $\mathrm{CO}_{2}$ concentration fell down until $630^{\circ} \mathrm{C}$ then increased till $\mathrm{T}_{\text {cr.2. }}$. The concentration of $\mathrm{VOC}$ and $\mathrm{CO}$ changed, but character of the changes was different. The peak concentration of $\mathrm{VCO}$ reached $2000 \mathrm{ppm}$ at 470 $570^{\circ} \mathrm{C}$ and decays to below detection at $800^{\circ} \mathrm{C}$. The inhibitive effect of the particles in fluidized bed on the processes involving radicals, which are responsible for increase of the $\mathrm{CO}$ concentration is clearly observed in $B$ regime. While bed temperature increase, instead of the expected decrease [CO], it rises to maximum concentration of $5000 \mathrm{ppm}$ at $780^{\circ} \mathrm{C}$. Then, at temperature near $\mathrm{T}_{\text {cr.2 }}[\mathrm{CO}]$ fell rapidly. This was caused by the change of the mechanism controlling the combustion at the transition between $B$ and $C$ regimes. Above $T_{\text {cr.2 }}$ spontaneous combustion inside the bubbles takes place, in a homogenous phase without solid particles present. There was no quenching effect from recombining radical adsorbed on the sand surface. Combustion in regime $\mathrm{C}$ is characterized by low $\mathrm{CO}$ and $\mathrm{VCO}$ concentration. $\mathrm{Al}$ most entire carbon was converted to $\mathrm{CO}_{2}$ (Figure 4A).
After introducing DCM (Figure 4A, B and C) or MCB (Figure $4 \mathrm{D}, \mathrm{E}$ and $\mathrm{F}$ ) to the inlet mixture changes of $\left[\mathrm{CO}_{2}\right],[\mathrm{CO}]$ and $[\mathrm{VOC}]$ retained its character. Increase of the bed temperature was accompanied by the decrease of $\left[\mathrm{CO}_{2}\right]$ till $630^{\circ} \mathrm{C}$. Under regime $\mathrm{B}$, above $630^{\circ} \mathrm{C}$ $\left[\mathrm{CO}_{2}\right]$ gradually increased, reaching a constant value after exceeding $\mathrm{T}_{\text {cr.2. }}$. The $\mathrm{CO}$ concentration increased according with temperature increased under regimes $\mathrm{A}$ and $\mathrm{B}$. The conversion $\mathrm{CO}$ to $\mathrm{CO}_{2}$ rapidly accelerated under regime $\mathrm{B}$ near to $\mathrm{T}_{\text {cr.2. }}$. During the second part of regime $\mathrm{B}$ the highest concentrations of $\mathrm{CO}$ were 6950 ppm, $7900 \mathrm{ppm}$ and $8300 \mathrm{ppm}$ corresponding with the concentration of DCM in inlet streams: 1100 ppm, 2700 ppm and $5350 \mathrm{ppm}$. CO concentrations resulting from the same amounts of MCB were $6725 \mathrm{ppm}, 6980 \mathrm{ppm}$ and $8035 \mathrm{ppm}$ (Figure 4E). When LPG was combusted in the presence of DCM (which introduced two chlorine atoms per each additional carbon atom in the reaction zone) the $\mathrm{CO}$ concentration was higher. Presence of $\mathrm{Cl}$ free radicals and $\mathrm{HCl}$ has influence on the $\mathrm{CO}$ oxidation. The main reaction oxidizing $\mathrm{CO}$ to $\mathrm{CO}_{2}$ is [23]:

$$
\mathrm{CO}+\mathrm{OH}->\mathrm{CO}_{2}+\mathrm{H}
$$

Important way of hydroxyl radical formation is by $\mathrm{H}$ radical via [15]:

$$
\mathrm{H}+\mathrm{O}_{2}->\mathrm{OH}+\mathrm{O}
$$


When chlorine compound is added to the combustible mixture, $\mathrm{Cl}$ and $\mathrm{HCl}$, compete with $\mathrm{CO}$ for $\mathrm{H}$ and $\mathrm{OH}$ radicals (1-2 vs. 4-5). It leads to inhibition of $\mathrm{CO}$ oxidation. Analyzing the changes of $\mathrm{CO}$ concentration $\left(\mathrm{CO}^{1}\right.$, $\mathrm{CO}^{3}$ lines, Figure $4 \mathrm{~B}$ and $\mathrm{E}$ ) it can be determined that this inhibition mechanism is significant under regime A and $\mathrm{B}$. Under regime $\mathrm{C}$, at higher temperature the concentration of $\mathrm{OH}$ is increased and catalytic processes involving chlorine is negligible.

In the middle of the regime $\mathrm{B}$ the efficiency of $\mathrm{CO}_{2}$ $\left(\mathrm{CO}_{2}^{1}\right.$ line, Figure 4A and $\left.\mathrm{D}\right)$ production increases, compared to experiment without chlorine additive. The mechanism reducing a negative effect of $\mathrm{HCl}$ on the formation of radicals substantial in carbon monoxide oxidation have been identified by Mueller et al [24]:

$$
\begin{aligned}
& \mathrm{HCl}+\mathrm{OH}->\mathrm{H}_{2} \mathrm{O}+\mathrm{Cl} \\
& \mathrm{Cl}+\mathrm{HO}_{2}->\mathrm{HCl}+\mathrm{O}_{2} \\
& \mathrm{CO}+\mathrm{OH}->\mathrm{CO}_{2}+\mathrm{H} \\
& \mathrm{H}+\mathrm{O}_{2}->\mathrm{OH}+\mathrm{O} \\
& \mathrm{H}_{2} \mathrm{O}+\mathrm{O}->\mathrm{OH}+\mathrm{OH}
\end{aligned}
$$

In total:

$$
\mathrm{CO}+\mathrm{HO}_{2}->\mathrm{CO}_{2}+\mathrm{OH}
$$

Under regime A when DCM or MCB was added, VOCs concentration was lower, in comparison to LPG combustion. This change indicates that below $\mathrm{T}_{\text {cr.1 }}$, there is possibility of reaction between chlorinated byproducts and fuel which accelerates decomposition of the latter. Maximum of $[\mathrm{VOC}]$ was observed between regime A and B when LPG alone was burnt. Addition of $\mathrm{CHCs}$ shifts VOC peak slightly to higher temperature. Near $\mathrm{T}_{\text {cr.2 }}$ VOC was completely destroyed.

\section{Chloroorganic compounds of the thermal decomposition of DCM}

The temperature of the fluidized bed is a factor influencing the concentrations of toxic by-products resulting from incomplete combustion of DCM.

Degree of DCM decomposition versus mean bed temperature is shown in Figure 5. The onset of DCM's degradation was observed at $230^{\circ} \mathrm{C}$. Under regime A as the mean bed temperature increases the concentration of DCM in the combustion by-products gradually decreased. When the bed's temperature reached $\mathrm{T}_{\text {cr.1 }}$ the concentration of DCM in the flue gases was c.a. $4 \%$ of its initial value. Above $\mathrm{T}_{\text {cr.1 }}$ DCM concentration was slightly increasing to reach a maximum of $8-10 \%$ of its initial value at $700^{\circ} \mathrm{C}$. Further increase of the mean bed temperature decreases concentration of DCM. Over $\mathrm{T}_{\mathrm{cr} .2}$ DCM was completely destroyed. Similar experiments

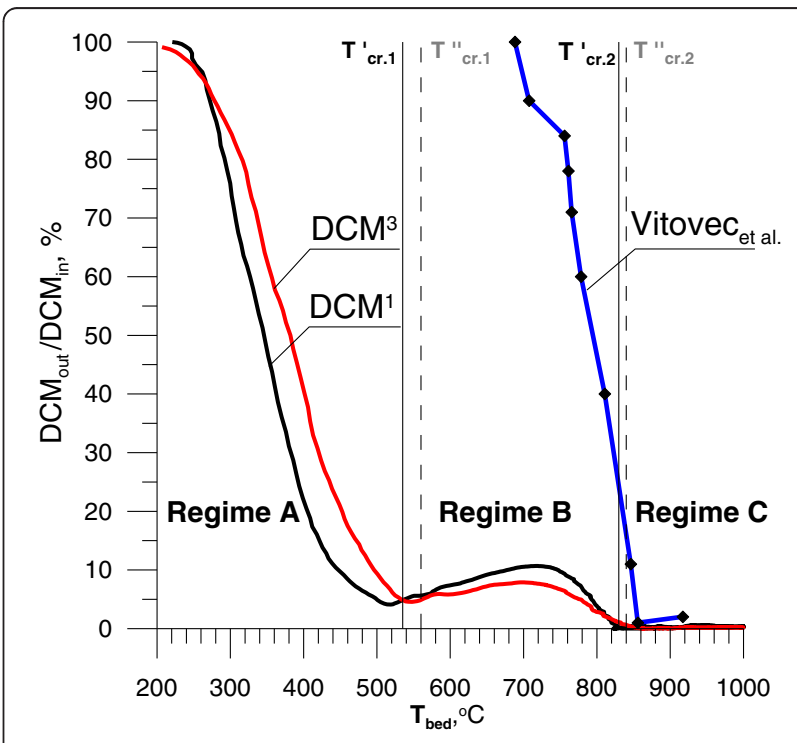

Figure 5 Degree of decomposition of $\mathrm{CH}_{2} \mathrm{Cl}_{2}$ for different temperature $\left(\mathrm{DCM}_{\text {in }}\right.$ and $\mathrm{DCM}_{\text {out }}$ are the inlet and outlet concentration of dichloromethane respectively).

carried out in the tubular reactor showed that beginning of degradation was observed at higher temperature $680^{\circ}$ $\mathrm{C}$ Vitovec et al. [25]. Moreover, 50\% of decomposition have been reached at $830^{\circ} \mathrm{C}$ compared to $350-400^{\circ} \mathrm{C}$ for our work. After a bubble is formed in the bed, the gaseous mixture is preheated to the temperature of the fluidized bed, and then, after delay needed to ignition the temperature rise further. It was calculated that the difference between temperature inside the bubble and mean temperature of emulsion phase in the fluidized bed is $400-500 \mathrm{~K}$ [22]. This effect is responsible for lowering of temperature of decomposition onset in fluidized bed in comparison with the tubular reactor.

Figure 6 illustrated the concentration of three chlorinated byproducts as a function of the mean bed temperature, when 1100 or $5350 \mathrm{ppm}$ of DCM were added into the LPG-air mixture. Formation of chloroform started at lower temperature $\left(280^{\circ} \mathrm{C}\right)$ than chloromethane $\left(340^{\circ} \mathrm{C}\right)$. Concentration of both substances above these temperatures increased to reach maximum in the regime $\mathrm{B} . \mathrm{CHCl}_{3}$ concentration was increasing and $\mathrm{CH}_{3} \mathrm{Cl}$ concentration was decreasing as the DCM stream increased. Under regime $\mathrm{A}$ increase of $\mathrm{T}_{\text {bed }}$ caused significant rise in the concentration of $\mathrm{COCl}_{2}$. Concentration of phosgene reached a maximum close to the first and second critical temperature at c.a. $500^{\circ} \mathrm{C}$ and $820^{\circ} \mathrm{C}$. Between these temperatures, when the bed's temperature exceeded $740^{\circ} \mathrm{C}$, the phosgene concentration temporarily dropped. This decrease of phosgene concentration was observed in regime $\mathrm{B}$ as $\mathrm{CHCl}_{3}$ and $\mathrm{CH}_{3} \mathrm{Cl}$ concentrations increased. Under regime $\mathrm{C}$, when $\mathrm{T}_{\text {bed }}$ exceeded $900^{\circ} \mathrm{C}$, the concentration of 

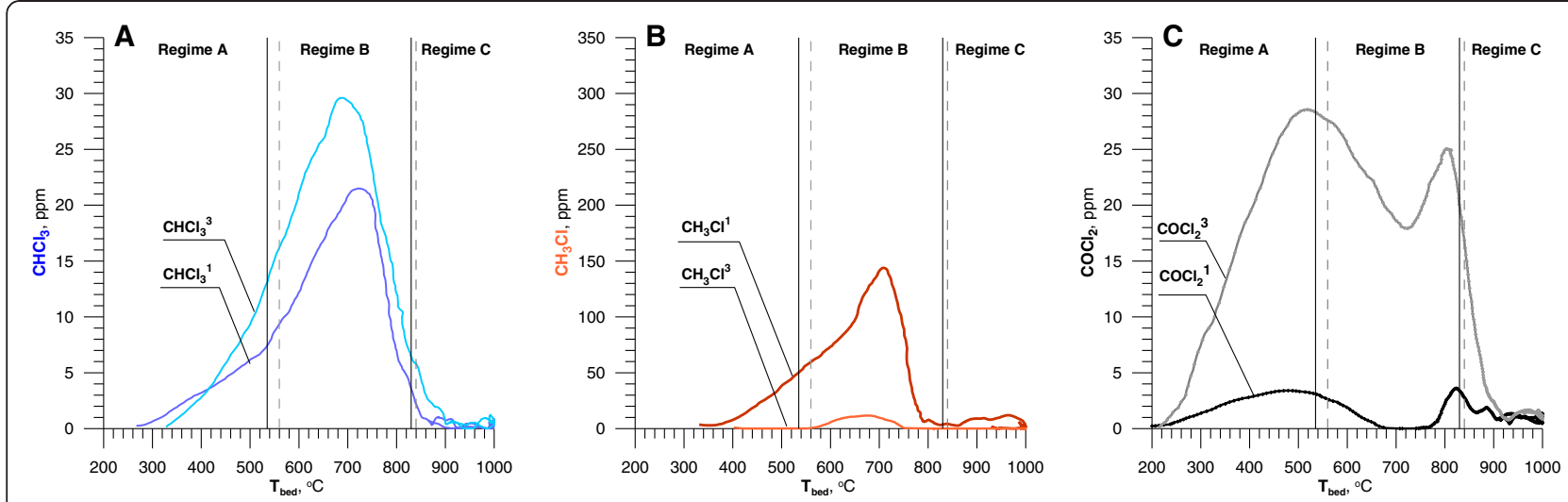

Figure 6 Chlorinated byproducts of DCM as a function of the mean bed temperature ( ${ }^{1}-1100$ ppm of DCM, ${ }^{3}-5350$ ppm DCM).

chlorinated byproduct drop near to zero. Above $900^{\circ} \mathrm{C}$ the main product of oxidation of DCM was hydrogen chloride. Introducing dichloromethane into the reactor with concentrations $1100 \mathrm{ppm}, 2700 \mathrm{ppm}$ and $5350 \mathrm{ppm}$ caused an increase of hydrogen chloride concentration to $2200 \mathrm{ppm}, 5400 \mathrm{ppm}$ and $10700 \mathrm{ppm}$ respectively.

In a homogenous combustion above the fluidized bed or inside the bubbles a significant role in oxidation of DCM play $\mathrm{H}$ radicals created during burning of hydrocarbon fuel. Initial attack on DCM can be started via reactions with $\mathrm{H}$ (12), $\mathrm{Cl}, \mathrm{O}$ and $\mathrm{OH}$ radicals or oxygen particles (13)[25]:

$$
\begin{aligned}
& \mathrm{CH}_{2} \mathrm{Cl}_{2}+\mathrm{H}->\mathrm{CH}_{2} \mathrm{Cl}+\mathrm{HCl} \\
& \mathrm{CH}_{2} \mathrm{Cl}_{2}+\left(\mathrm{O}_{2}, \mathrm{OH}, \mathrm{O}, \mathrm{Cl}\right)- \\
& \quad>\mathrm{CHCl}_{2}+\left(\mathrm{HO}_{2}, \mathrm{H}_{2} \mathrm{O}, \mathrm{OH}, \mathrm{HCl}\right)
\end{aligned}
$$

Under fuel-lean condition rather $\mathrm{CHCl}_{2}$ radicals will be created than $\mathrm{CH}_{2} \mathrm{Cl}$ [26].

According to Chi [27] the created $\mathrm{CHCl}_{2}$ radical reacts with radical of a chlorine to form chloroform:

$$
\mathrm{CHCl}+\mathrm{Cl}+\mathrm{M}->\mathrm{CHCl}_{3}+\mathrm{M}
$$

The observed increase of the DCM concentration when the bed's temperature was increased from $550^{\circ} \mathrm{C}$ to $700^{\circ} \mathrm{C}$ may be the result of one of the following reactions:

$$
\mathrm{CH}_{2} \mathrm{Cl}+\mathrm{Cl}+\mathrm{M}->\mathrm{CH}_{2} \mathrm{Cl}_{2}+\mathrm{M}
$$

When methane is present in the reaction zone (e.g. it's formed as a transient product of LPG combustion) the following reaction is possible:

$$
\mathrm{CH}_{4}+\mathrm{Cl}->\mathrm{HCl}+\mathrm{CH}_{3}
$$

The methyl radicals can recombine with chlorine to form methyl chloride:

$$
\mathrm{CH}_{3}+\mathrm{Cl}+\mathrm{M}->\mathrm{CH}_{3} \mathrm{Cl}+\mathrm{M}
$$

In the second mechanism of $\mathrm{CH}_{3} \mathrm{Cl}$ formation an important role play $\mathrm{CH}_{2} \mathrm{Cl}$ radicals formed in reaction (12) [28]:

$$
\mathrm{CH}_{2} \mathrm{Cl}+\mathrm{H}_{2}->\mathrm{CH}_{3} \mathrm{Cl}+\mathrm{H}
$$

The decrease in methyl chloride concentration along with the increase in DCM concentration may indicate that reaction (18) (limited by $\mathrm{CH}_{2} \mathrm{Cl}$ radical concentration) has a dominating role in the fluidized bed. That radical takes part in recreating DCM during regime $\mathrm{B}$ according to reactions (15) (Figure 5). In temperature above $900^{\circ} \mathrm{C}$ both $\mathrm{CHCl}_{3}$ and $\mathrm{CH}_{3} \mathrm{Cl}$ react completely.

To create phosgene during DCM decomposition structure of two chlorine atoms bound to carbon atom is needed [25]. Phosgene formation can be initiated by chloroform dissociation [29] as follows:

$$
\mathrm{CHCl}_{3}->\mathrm{CCl}_{2}+\mathrm{HCl}
$$

The $\mathrm{CCl}_{2}$ radical can be oxidized to phosgene:

$$
\mathrm{CCl}_{2}+\mathrm{O}_{2}->\mathrm{COCl}_{2}+\mathrm{O}
$$

$\mathrm{COCl}_{2}$ can also be formed during DCM destruction according to the proposed mechanism:

$$
\begin{aligned}
& \mathrm{CH}_{2} \mathrm{Cl}_{2}+\mathrm{OH}->\mathrm{CHCl}_{2}+\mathrm{H}_{2} \mathrm{O} \\
& \mathrm{CHCl}_{2}+\mathrm{OH}->\mathrm{CCl}_{2}+\mathrm{H}_{2} \mathrm{O} \\
& \mathrm{CCl}_{2}+\mathrm{O}_{2}->\mathrm{COCl}_{2}+\mathrm{O}
\end{aligned}
$$

Phosgene can be further transformed to $\mathrm{CO}$ :

$$
\begin{aligned}
& \mathrm{COCl}_{2}+\mathrm{X}->\mathrm{COCl}+\mathrm{XCl} \\
& \mathrm{COCl}_{2}+\mathrm{X}->\mathrm{COCl}+\mathrm{XCl}
\end{aligned}
$$




$$
\mathrm{COCl}+\mathrm{M}->\mathrm{CO}+\mathrm{Cl}+\mathrm{M}
$$

where $\mathrm{X}=\mathrm{Cl}, \mathrm{H}, \mathrm{O}, \mathrm{OH}$.

Above $900^{\circ} \mathrm{C}$ phosgene concentration was too small to be measured by the apparatus.

\section{Chloroorganic compounds of the thermal decomposition of $\mathrm{MCB}$}

The results support that as with the decomposition of DCM, the degree of decomposition of MCB strongly dependent on temperature of the bed.

Figure 7 presents the decay of $\mathrm{MCB}$ versus the mean bed temperature, when different amount of $\mathrm{MCB}$ was injected into LPG-air mixture. MCB decomposition started at c.a. $300^{\circ} \mathrm{C}$ and proceeded slower than DCM decomposition. DCM reaching 50\% decomposition at $400^{\circ} \mathrm{C}$ compared to $540^{\circ} \mathrm{C}$ for $\mathrm{MCB}$ (Figures 5 and 7 ). During regime $\mathrm{B}$ at $680^{\circ} \mathrm{C}$ the concentration of $\mathrm{MCB}$ reached c.a. $5 \%$ of the initial value (190 ppm). Afterwards concentration of MCB was increased to $270 \mathrm{ppm}$ at $760^{\circ} \mathrm{C}$. Over $900^{\circ} \mathrm{C}$ all $\mathrm{MCB}$ was destroyed. Comparison of our results to [30] Higgins et al. or [31] Fadli et al. studies, the total decomposition in the FBC occurs at higher temperatures than during thermal oxidation in flow reactor, but process begins at lower temperature. Again, the values of $T_{\text {cr. } 1}$ and $T_{\text {cr. } 2}$ are decisive factors on degree of the MCB conversion.

Below $825^{\circ} \mathrm{C}$ the following reactions initiating the MCB decomposition are possible [31]:

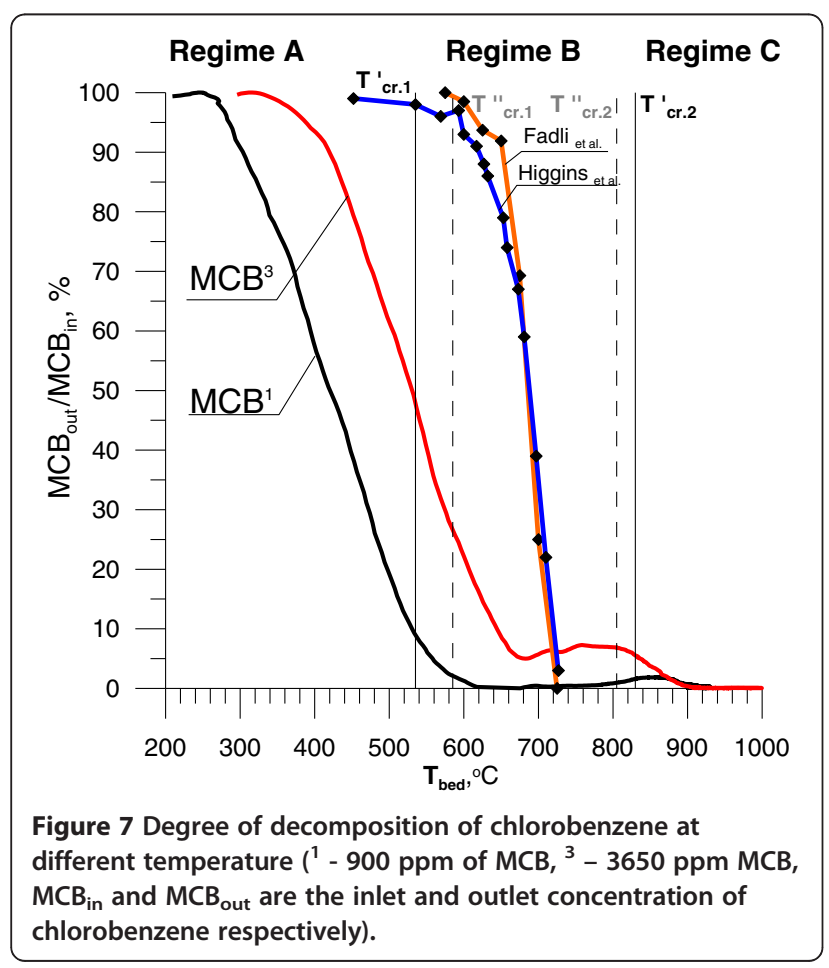

Separation of chlorine and the formation of the phenol radical:

$$
\mathrm{C}_{6} \mathrm{H}_{5} \mathrm{Cl}->\mathrm{Cl}+\mathrm{C}_{6} \mathrm{H}_{5}(\mathrm{cy})
$$

The rupture of bonds between carbon and hydrogen:

$$
\mathrm{C}_{6} \mathrm{H}_{5} \mathrm{Cl}->\mathrm{H}+\mathrm{C}_{6} \mathrm{H}_{4} \mathrm{Cl}
$$

The breakdown of benzene ring and formation of ethyne and vinyl chloride:

$$
\mathrm{C}_{6} \mathrm{H}_{5} \mathrm{Cl}->\mathrm{C}_{6} \mathrm{H}_{5} \mathrm{Cl}(\mathrm{l})->\mathrm{C}_{2} \mathrm{HCl}+2 \mathrm{C}_{2} \mathrm{H}_{2}
$$

Abstraction of the hydrogen or chlorine by an oxygen particle:

$$
\begin{aligned}
& \mathrm{C}_{6} \mathrm{H}_{5} \mathrm{Cl}+\mathrm{O}_{2}->\mathrm{C}_{6} \mathrm{H}_{4} \mathrm{Cl}+\mathrm{HO}_{2} \\
& \mathrm{C}_{6} \mathrm{H}_{5} \mathrm{Cl}+\mathrm{O}_{2}->\mathrm{C}_{6} \mathrm{H}_{5}+\mathrm{ClO}_{2}
\end{aligned}
$$

The perceivable products of incomplete combustion of hydrocarbons under regime $B$ were methane and ethyne (Figure 8), which confirms the results observed by [31] Fadli et al.

From reaction 27 phenyl radicals can produce ethyne via:

$$
\begin{aligned}
& \mathrm{C}_{6} \mathrm{H}_{5}(\mathrm{cy})->\mathrm{C}_{6} \mathrm{H}_{5}(\mathrm{I}) \\
& \mathrm{C}_{6} \mathrm{H}_{5}(\mathrm{l})->\mathrm{C}_{4} \mathrm{H}_{3}+\mathrm{C}_{2} \mathrm{H}_{2}
\end{aligned}
$$

The reaction of methane production can involve methyl radicals, which come from propane combustion, as follows:

$$
\mathrm{CH}_{3}+\mathrm{C}_{6} \mathrm{H}_{5}(\mathrm{cy})->\mathrm{C}_{6} \mathrm{H}_{5}(\mathrm{I})
$$

Introduction $\mathrm{MCB}$ to the system not caused a significant increase in the concentration of benzene, but shifted its maximum concentration to the higher temperature.

During the combustion of LPG with MCB the main gas product containing chlorine was hydrogen chloride. Over $900^{\circ} \mathrm{C}$ the conversion factor of chlorine in MCB to hydrogen chloride was $92-100 \%$.

Regime B is characterized by the occurrence of the highest concentrations of products from incomplete MCB decomposition (Figure 9). In received results, the most interesting is the low concentration of phosgene. Phosgene concentration was below detection limit despite the presence of chloroform (which can be the precursor of phosgene) in the reaction zone at concentration similar to that for DCM decomposition. This means that in the conditions created in the fluidized bed the rate of the reaction (19-20) is too slow to obtain comparable amounts of phosgene during degradation of MCB. This also shows that the presence of phosgene during DCM degradation is a result of 

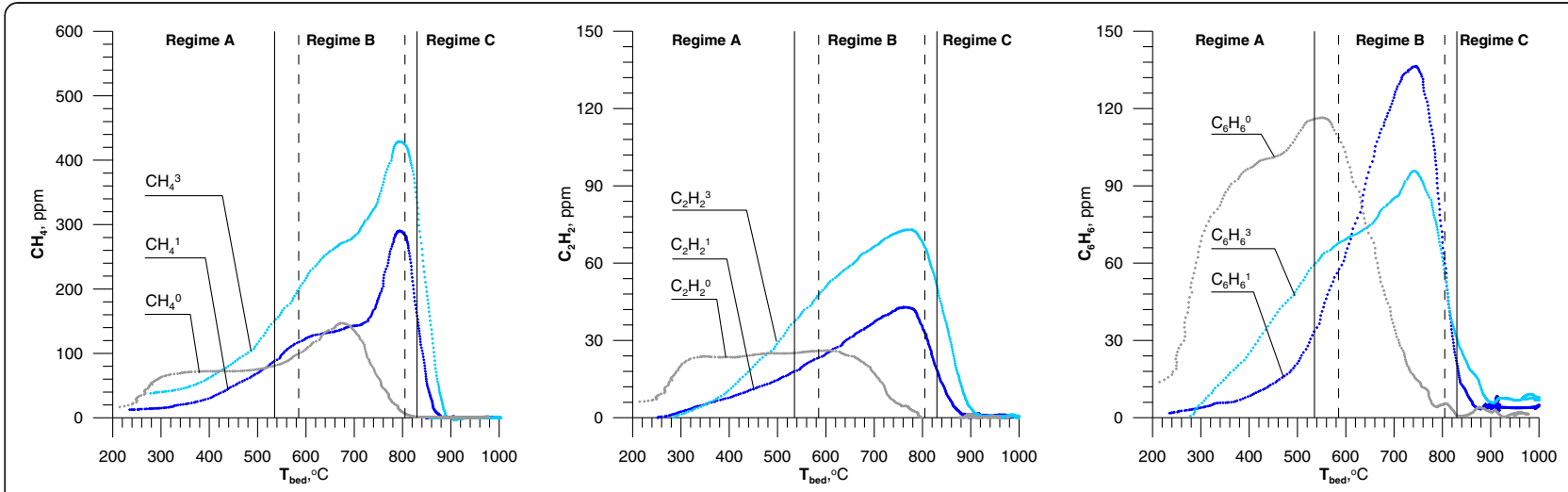

Figure 8 The effect of adding MCB on $\left[\mathrm{C}_{2} \mathrm{H}_{2}\right],\left[\mathrm{CH}_{4}\right],\left[\mathrm{C}_{6} \mathrm{H}_{6}\right]$ in flue gases $\left({ }^{0}-0 \mathrm{ppm} \mathrm{MCB}{ }^{1}-900 \mathrm{ppm}\right.$ MCB, ${ }^{3}-3650 \mathrm{ppm}$ MCB).

Continuous and dashed vertical lines are defined below Figure 2.

reactions (21-23). Above $900^{\circ} \mathrm{C}$, under regime $\mathrm{C}$, concentrations of chloride containing products of incomplete combustion are too little to be determined.

\section{Influence of presence of chlorine compounds on $\mathrm{NO}_{\mathrm{x}}$ formation}

During combustion of fuels in the air nitrogen oxides are formed by oxidation of $\mathrm{N}_{2}$ or nitrogen fuel. The first process runs according to the Zeldovich mechanism [32], which is important when the temperature of the reagents exceeds $1400^{\circ} \mathrm{C}$, or prompt mechanism, at lower temperature $[16,33]$. In the latter mechanism crucial role play $\mathrm{CH}_{\mathrm{x}}$ forming $\mathrm{HCN}, \mathrm{CN}, \mathrm{NH}$ and hence $\mathrm{NO}_{\mathrm{x}}$.

As Figure 10 shows $\mathrm{NO}_{\mathrm{x}}$ concentration was higher when the combustion took place in the presence of chloroorganic compounds (Figure 10). The change was the result of a presence of additional pool of radicals that form quickly from $\mathrm{CHCs}$ even at relatively low temperature. These radicals begin a chain reaction leading to the increase concentration of $\mathrm{CH}, \mathrm{CH}_{2}$ radicals and act to promote the formation of nitrogen oxides from $\mathrm{N}_{2}$.

\section{Conclusions}

Thermal decomposition of chlorinated hydrocarbons during its combustion in mixture with supporting gaseous fuel, in the condition created by fluidized bed of sand, takes place in bubbles floating inside a bed's dense phase. In relation to combustion in the tubular reactor, process of their decomposition occurs in a relatively lower temperature. This is due to specific role of the emulsion phase of fluidized bed. By contact with this phase mixture of utilized compound with air and supporting fuel are preheated to the temperature of the fluidized bed. After this preheating, the gaseous mixture (in the bubbles) ignited. When heat is released, temperature of the mixture in the bubbles increased. Due to the limited heat transfer between gases in the bubbles and the bed material, gases can reach maximum value of $1300^{\circ} \mathrm{C}$
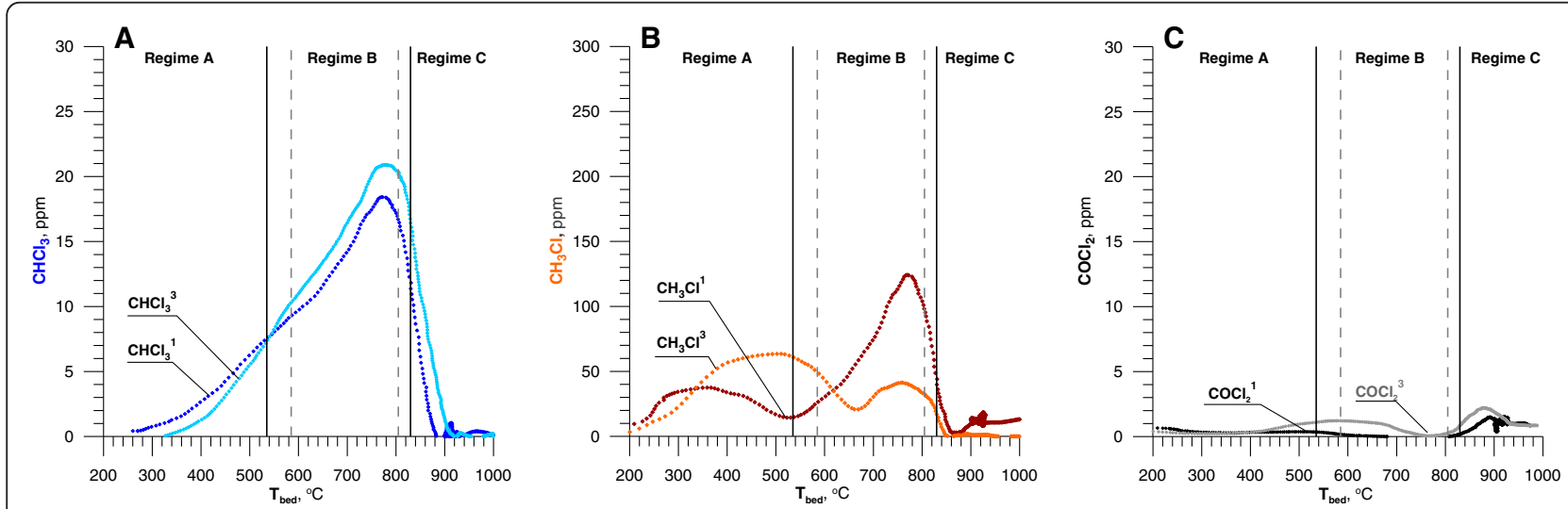

Figure 9 Chlorinated byproducts of $\mathrm{C}_{6} \mathrm{H}_{5} \mathrm{Cl}$ decomposition as a function of the mean bed temperature $\left({ }^{1}-900\right.$ ppm $\mathrm{MCB},{ }^{3}-3650$ ppm MCB). Continuous and dashed vertical lines are defined below Figure 2. 

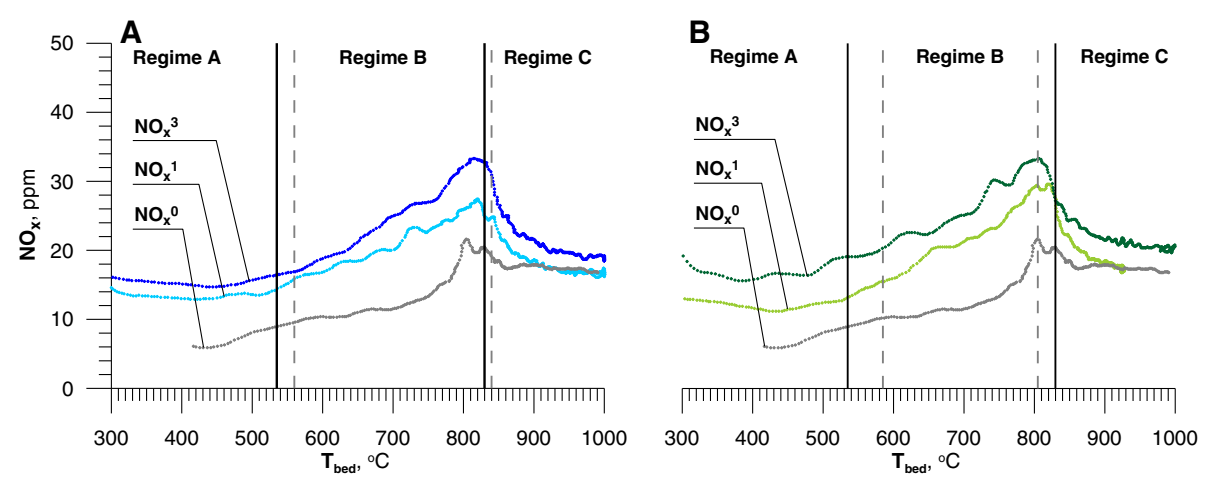

Figure $10 \mathrm{~A}$ - Effect of adding DCM on $\left[\mathrm{NO}_{x}\right]$ in flue gases $\left({ }^{1}-1100\right.$ ppm DCM, ${ }^{3}-5350$ ppm DCM). B - Effect of adding $\mathrm{C}_{6} \mathrm{H}_{5} \mathrm{Cl}$ on $\left[\mathrm{NO}_{x}\right]$ in flue gases ('- 900 ppm MCB, ${ }^{3}-3650$ ppm MCB) ${ }^{0}-0 \mathrm{~mL} / \mathrm{s}$ DCM or MCB.

or more while temperature of bed material is e.g. $850^{\circ} \mathrm{C}$ $[14,22]$. It means that the effective temperature of the degradation of the pollutant is few hundred degrees higher than the temperature measured in the reactor. What is more, intensive mixing in the bed causes the alignment of the fluidized bed temperature. This ensures appropriate conditions for complete conversion of the reactants. Combustion of hydrocarbon (supporting) fuel in such an environment ensures stable conditions and is a source of $\mathrm{H}$ and $\mathrm{OH}$ radicals, which are necessary for disintegration of chloroorganic substances. On the other hand, adding to the fuel chlorine compounds influences the combustion process which leads to some changes of the values of critical temperatures $\mathrm{T}_{\text {cr.1 }}$ and $\mathrm{T}_{\text {cr.2. }}$. These small shifts do not make impossible to carry on thermal degradation of given additives. It was confirmed that phosgene can be formed only if, the oxidized substance is able to create a structure of two chlorine atoms bound to carbon atom. Therefore, in the case of chlorobenzene, the concentration of phosgene in the whole temperature range, was below detection limit, while during the oxidation of DCM reached a value 11 times higher, but only if the bed temperature is lower than $900^{\circ} \mathrm{C}$.

If the main efficiency criterion is the minimization of $\mathrm{CO}$ and $\mathrm{NO}_{\mathrm{x}}$ concentration and preventing the formation of intermediate species from DCM or MCB oxidation, then it is preferable to carry out the process during regime $\mathrm{C}$ of the combustion in the fluidized bed. The optimum range for the process is limited by the minimum temperature of $900^{\circ} \mathrm{C}$ and the maximum temperature of the bed's material. When the material used in the bed is $\mathrm{SiO}_{2}$ the temperature should not be higher than $1100^{\circ} \mathrm{C}$. In a laboratory-scale reactor it has been found that even if the reactor has no automatic temperature regulation it is possible to have the temperature variation range at $\pm 10 \mathrm{~K}$. In a larger scale installation, which includes an automatic temperature regulation system, it is achievable to get the designated temperature range.

Notice: Some of the theses presented in this work, were previously published in Polish in: Przemysl Chemiczny 91 (5), 2012, pp. $912-919$

\section{Competing interests}

The authors declare that they have no competing interests.

\section{Authors' contributions}

All authors were equally involved in all stages of research work. All authors read and approved the final manuscript.

\section{Author details}

'Department of Thermal Engineering and Air Protection, Faculty of Environmental Engineering, Cracow University of Technology, Warszawska 24, Cracow 31-155, Poland. ${ }^{2}$ Department of Inorganic Chemistry and Technology, Faculty of Chemical Engineering and Technology, Cracow University of Technology, Warszawska 24, Cracow 31-155, Poland.

Received: 6 September 2012 Accepted: 2 January 2013

Published: 6 January 2013

\section{References}

1. Atkins PW (1998) Physical chemistry. Freeman, New York

2. van der Vaart DR (1988) The chemistry of premixed hydrocarbon/air combustion in a fluidized bed. Combust Flame 71:35-39

3. Ribeiro L, Pinho C (2004) Generic behaviour of propane combustion in fluidized beds. Chemical Engineering Research and Design 82:1597-1603

4. Hesketh RP, Davidson JF (1991) Combustion of methane and propane in an incipiently fluidized bed. Combust Flame 85:449-467.

5. Hayhurst AN (1991) Does carbon monoxide burn inside a fluidized bed? A new model for the combustion of coal char particles in fluidized beds. Combust Flame 85:155-168

6. Dennis JS, Hayhurst AN, Mackley IG (1982) The ignition and combustion of propane/air mixtures in a fluidised bed. In: Proceedings of the 19th International Symposium on Combustion, 19th edn. Elsevier Inc, pp 1205-1212

7. Saxena SC, Rao NS, Thomas LA (1993) Combustion of propane and fluidized bed co-combustion. Energy 18:1045-1057

8. Pre P, Hemati M, Marchand B (1998) Study on natural gas combustion in fluidized beds: Modelling and experimental validation. Chemical Engineering Science 53:2871-2883

9. Bulewicz EM (2002) Free radicals, combustion and fluidised beds. In: Grace $J R$, Zhu J, de Lasa H (eds) Proceedings of the 7th International Conference on CFBC., Canada, pp 13-26 
10. Bulewicz EM, Żukowski W, Kandefer S, Pilawska M (2003) Flame flashes when bubbles explode during the combustion of gaseous mixtures in a bubbling fluidized bed. Combust Flame 132:319-327

11. Baron J, Bulewicz EM, Kandefer S, Pilawska M, Żukowski W, Hayhurst AN (2009) Combustion of hydrogen in a bubbling fluidized bed. Combust Flame 156:975-984

12. Żukowski W (1999) Acoustic effects during the combustion of gaseous fuels in a bubbling fluidized bed. Combust Flame 117:629-635

13. Baron J, Bulewicz EM, Zabagło J, Żukowski W (2012) Propagation of reaction between bubbles with a gas burning in a fluidised bed. Flow, Turbulence and Combustion 88:479-502

14. Żukowski W (2003) A simple model for explosive combustion of premixed natural gas with air in a bubbling fluidized bed of inert sand. Combust Flame 134:399-409

15. Bulewicz EM, Janicka E, Kandefer S (1989) Halogen inhibition of CO oxidation during the combustion of coal in a fluidized bed. In: Arnold M (ed) Proceedings of the 10th International Conference on Fluidized Bed Combustion, FBC - Technology for Today. Manaker, pp 163-168

16. Baron J, Bulewicz EM, Żukowski W, Kandefer S, Pilawska M (2002) Combustion of hydrocarbon fuels in a bubbling fluidized Bed. Combust Flame 128:410-421

17. Chang WD, Karra SB, Senkan SM (1987) A computational study of chlorine inhibition of CO flames. Combust Flame 69:113-122

18. Roesler JF, Yetter RA, Dryer FL (1995) Kinetic interactions of $\mathrm{CO}, \mathrm{NO}_{x,}$ and $\mathrm{HCl}$ emissions in postcombustion gases. Combust Flame 100:495-504

19. Gokulakrishnan P, Lawrence AD (1999) An Experimental Study of the Inhibiting Effect of Chlorine in a Fluidized Bed Combustor. Combust Flame 116:640-652

20. Wei X, Wang Y, Liu D, Sheng H (2009) Influence of $\mathrm{HCl}$ on CO and NO emissions in combustion. Fuel 88:1998-2003

21. Julien S, Brereton CMH, Lim CJ, Grace JR, Anthony EJ (1996) The effect of halides on emissions from circulating fluidized bed combustion of fossil fuels. Fuel 75:1655-1663

22. Żukowski W (2005) Methane and ethane combustion in an inert fluidized bed. In: Proceedings of the 18th International Conference on Fluidized Bed Combustion. Copyright by ASME, Canada, pp 453-461

23. Gardiner WC Jr (2000) Gas-Phase Combustion Chemistry. Springer - Verlag, New York

24. Mueller C, Kilpinen P, Hupa M (1998) Influence of $\mathrm{HCl}$ on the homogeneous reactions of $\mathrm{CO}$ and $\mathrm{NO}$ in postcombustion conditions - A kinetic modeling study. Combust Flame 113:579-588

25. Vitovec W, Koshland CP, Lucas D, Sawyer RF (1996) The Destruction of Methylene Chloride in Lean Post- Flame Conditions. Combustion Science and Technology 116-117:153-166

26. Sgro LA, Koshland CP, Lucas D, Sawyer RF (2000) Postflame Reaction Chemistry of Dichloromethane: Variations in Equivalence Ratio and Temperature. Combust Flame 20:492-503

27. Chi Y, Wang B, Yan J, Ni M (2009) Influence of chlorine on methane oxidation. J Environ Sci (Beijing, China) 21:1315-1320

28. Ho W, Barat RB, Bozzelli JW (1992) Thermal reaction of $\mathrm{CH}_{2} \mathrm{Cl}_{2}$ in $\mathrm{H}_{2} / \mathrm{O}_{2}$ Mixtures: Implication for chlorine Inhibition of $\mathrm{CO}$ conversion to $\mathrm{CO}_{2}$ Combust Flame 88:265-295

29. Taylor PH, Dellinger B, Tirey DA (1991) Oxidative pyrolysis of $\mathrm{CH}_{2} \mathrm{Cl}_{2}, \mathrm{CHCl}_{3}$, and $\mathrm{CCl}_{4}-1$ : incineration implications. Int J Chem Kinet 23:1051-1074

30. Higgins B, Thomson MJ, Lucas D, Koshland CP, Sawyer RF (2001) An experimental and numerical study of the thermal oxidation of chlorobenzene. Chemosphere 42:703-717

31. Fadli A, Briois C, Baillet C, Sawerysyn JP (1999) Experimental study on the thermal oxidation of chlorobenzene at $575-825^{\circ} \mathrm{C}$. Chemosphere 38:2835-2848

32. Zeldovich YB (1946) The oxidation of nitrogen in combustion and explosions. Acta Physicochem USSR 21:577

33. Fenimore CP (1971) Formation of Nitric Oxide in Premixed Hydrocarbon Flames. Symposium (International) on Combustion 13:373-380

doi:10.1186/1752-153X-7-2

Cite this article as: Olek et al:: Thermal decomposition of selected chlorinated hydrocarbons during gas combustion in fluidized bed. Chemistry Central Journal 2013 7:2.

\section{Publish with ChemistryCentral and every scientist can read your work free of charge \\ "Open access provides opportunities to our colleagues in other parts of the globe, by allowing anyone to view the content free of charge." \\ W. Jeffery Hurst, The Hershey Company.}

- available free of charge to the entire scientific community

- peer reviewed and published immediately upon acceptance

- cited in PubMed and archived on PubMed Central

- yours - you keep the copyright

Submit your manuscript here:

http://www.chemistrycentral.com/manuscript/<smiles>c1ccccc1</smiles>

Chemistry Central 